\title{
Autohydrolysis Pretreatment of Castor Plant Pruning Residues to Enhance Enzymatic Digestibility and Bioethanol Production
}

\author{
José A. Rodríguez-de la Garza, ${ }^{a}$ David Castillo-Quiroz, ${ }^{\mathrm{b}}$ Leopoldo J. Rios-González, ${ }^{\mathrm{a}}$ \\ Thelma K. Morales-Martínez, ${ }^{\mathrm{a}}$ José A. González-Fuentes, ${ }^{\mathrm{c}}$ Luis A. Valdez-Aguilar, ${ }^{\mathrm{c}}$ and \\ Miguel A. Medina-Morales ${ }^{\mathrm{a}, *}$
}

\begin{abstract}
Castor plant is used commonly for oil extraction and biodiesel synthesis. However, the residues during pruning are not being used effectively. These residues have the potential to be used as feedstock to produce bioethanol and other by-products. The present work assessed the eco-friendly autohydrolysis pretreatment of castor plant pruning residues at different severity factors $\left(R_{0}\right)$, applying a range of temperatures from $100^{\circ} \mathrm{C}$ to 200 ${ }^{\circ} \mathrm{C}$. The hydrolysis of pretreated solids was carried out using a commercial cellulases complex at different solid and enzyme loadings. The enzymatic hydrolysate with a higher glucose concentration was further subjected to fermentation using Saccharomyces cerevisiae ATCC 4126. The results showed an efficient xylan hydrolysis $(77.5 \%)$ and a preservation of glucan up to $83 \%$ in the solids pretreated at an $R_{0}$ of 5.78 . The enzymatic hydrolysis of the pretreated solids at an $R_{0}$ of 5.78 showed a glucose release of 2.9-fold higher than non-pretreated material. In the hydrolysate fermentation, a maximum ethanol production of $50.5 \mathrm{~g} / \mathrm{L}$ was achieved (equivalent to $6.4 \% \mathrm{v} / \mathrm{v}$ ), corresponding to a conversion efficiency of $98 \%$ and a biomass-to-ethanol conversion yield of $93.0 \mathrm{~g}$ of ethanol per kilogram of feedstock.
\end{abstract}

Keywords: Autohydrolysis pretreatment; Bioethanol; Castor plant pruning residues; Enzymatic hydrolysis

Contact information: a: Departamento de Biotecnología, Facultad de Ciencias Químicas, Universidad Autónoma de Coahuila, Blvd. V. Carranza, C.P. 25280, Saltillo, Coahuila de Zaragoza, México; b: Campo Experimental Saltillo-INIFAP. Carretera Saltillo-Zacatecas km. 8.5 Núm. 9515, Hacienda de Buena Vista C.P. 25315, Saltillo, Coahuila de Zaragoza, México; c: Departamento de Horticultura, Universidad Autónoma Agraria Antonio Narro. Calzada Antonio Narro 1923, Buena Vista, Saltillo, Coahuila. México, C.P. 25315; *Corresponding author: miguel.medina@uadec.edu.mx

\section{INTRODUCTION}

Ricinus communis L. (castor plant) is a nonedible oil crop that is a member of the family Euphorbiaceae (Bauddh et al. 2015; Tropicos 2018). Castor plants tolerate a wide variety of weather conditions (they are commonly found as weeds alongside streams and polluted water) and have high biomass productivity (Vinayaka et al. 2017). Castor oil is conventionally used for a variety of industrial, cosmetic, and medical applications (Soni and Dhiman 2017); additionally, it is used for biodiesel production (Torrentes-Espinoza et al. 2017). During the period from 2004 to 2009, six industrial biodiesel plants were built in Mexico. Currently, due to the lack of a market and an insufficient supply of raw materials, these plants are not in operation (Montero et al. 2015). Recently, Mexico has started taking action towards the production and use of renewable and sustainable biofuels. In 2017, the first biodiesel plant from castor oil started operations in Mexico (FIRCO 
2017). Castor plants grow quickly under conditions of good soil fertility, rapidly reaching a height of 3 to 6 meters, and at this height, pruning is recommended, generating a massive quantity of lignocellulosic residue (Vinayaka et al. 2017). Currently, these residues are not fully used, although they could be used as adsorbents in wastewater treatment processes (Santhi et al. 2010), polymeric composites (Vinayaka et al. 2017), biomass for pyrolysis (Kaur et al. 2018), and feedstock for bioethanol production (Bateni et al. 2014; Althuri et al. 2017). Hydrolysable sugars in the stem and leaf have the potential to be transformed into diverse important products such as bioethanol. In almost all second-generation $(2 \mathrm{G})$ processes for bioethanol production from lignocellulosic residues, there is a pretreatment step of the raw material to increase its digestibility and to improve the hydrolysis of the cellulose to obtain fermentable sugars (Díaz-Blanco et al. 2018; Jiang et al. 2020; Kumar et al. 2020). The use of these residues for ethanol production was first reported by Bateni et al. (2014), and castor stem seed cake and leaves were pretreated separately using sodium hydroxide at high temperatures. Althuri et al. (2017) reported the use of a blend of castor plant residues, Saccharum spontaneum L. and Saccharum officinarum L. Poaceae that was enzymatically pretreated (Tropicos 2018). The autohydrolysis pretreatment method uses only water. This method provides a simple, low-cost, and environmentally friendly pretreatment technology to obtain a material with high cellulose content by means of solubilization of hemicellulose (Ríos-González et al. 2017). To date, there have been no other reports of pretreated castor plant biomass using a hydrothermal pretreatment method (autohydrolysis or steam explosion). The use of these methods for pretreatment generates high value by-products (e.g., xylooligosaccharides) during depolymerization of hemicellulose in the liquid phase. The present work assessed the autohydrolysis pretreatment of castor plant pruning residues for ethanol production with the potential of widening the biorefinery utilization of this crop.

\section{EXPERIMENTAL}

\section{Feedstock}

Pruned biomass (stems, leaves, and petioles) was collected from a castor plant that had a height of $2.1 \mathrm{~m}$ and an age of 5 months from an experimental plantation for oil production of the Soil Department of the Universidad Autonoma Agraria Antonio Narro (UAAAN) located in the municipality of Saltillo, Coahuila, Mexico (latitude $25^{\circ} 23^{\prime}$ North, longitude $101^{\circ} 00^{\prime}$ West, altitude $1742 \mathrm{~m}$ ). Before drying the pruned biomass, stems were manually cut to a size of 5 to $10 \mathrm{~cm}$ in length to facilitate further milling. The biomass was dried for further use in a Koleff Tray dehydrator (model KL10, Queretaro, Mexico) at $45{ }^{\circ} \mathrm{C}$ until the moisture content was less than $10 \%$ of the total weight. The dried mixture (material) was milled and sieved in a Retsch SM100 cutting mill (Retsch SM100, Retsch, Haan, Germany) to a particle size of $2 \mathrm{~mm}$ and subsequently stored at room temperature in hermetic containers.

\section{Material Characterization}

The moisture content of the material was determined in a thermobalance (OHAUS, Parsippany, NJ). Extractives were removed and determined as described by the National Renewable Energy Laboratory (NREL) analytical method NREL/TP-510-42619 (Sluiter et al. 2005). Structural carbohydrates (glucan and xylan) and lignin quantification was determined as described by Ríos-González et al. (2017). Ash and protein contents were 
determined using the NREL/TP-510-42622 protocol (Sluiter et al. 2008) and by the Kjeldahl method (Morales-Martinez et al. 2017), respectively.

\section{Autohydrolysis Pretreatment}

Autohydrolysis pretreatments were carried out in a $3.75 \mathrm{~L}$ agitated stainless steel reactor (model 4551, Parr Instruments, IL, USA) equipped with a temperature controller (model 4838, Parr Instruments). The reactor was loaded with $200 \mathrm{~g}$ (dry weight base) of material and $1.2 \mathrm{~L}$ of distilled water, resulting in a solids loading of $16.6 \%(\mathrm{w} / \mathrm{v})$. The resulting mixture was hydrated for $30 \mathrm{~min}$ before pretreatment at room temperature. All experiments were conducted in triplicate and under agitation at $200 \mathrm{rpm}$.

The severity factors $\left(R_{0}\right)$ of the autohydrolysis pretreatment were calculated considering the heating up and cooling down time, plus the isothermal regime established according to Eq. 1 proposed by Chornet and Overend (2017),

$$
\begin{gathered}
R_{0}=\left[R_{0 \text { HEATING }}+R_{0 \text { ISOTHERMALPROCESSING }}+R_{0 \text { COOLING }}\right]= \\
=\left[\int_{0}^{t_{M A X}} \exp \left(\frac{T(t)-T_{R E F}}{\Omega}\right) d t+\int_{\text {ISOI }}^{I S O F} \exp \left(\frac{T_{(t)}-T_{R E F}}{\Omega}\right) d t+\int_{0}^{t_{M A X}} \exp \left(\frac{T^{\prime}(t)-T_{R E F}}{\Omega}\right) d t\right]
\end{gathered}
$$

where $t_{M A X}$ is the time (min) needed to achieve the maximum temperature $\left(T_{M A X},{ }^{\circ} \mathrm{C}\right) ; T(t)$ and $T^{\prime}(t)\left({ }^{\circ} \mathrm{C}\right)$ are the temperature profiles in heating and cooling, respectively; $\omega$ and $T_{R E F}$ are parameters that also have been reported $\left(\Omega=14.75{ }^{\circ} \mathrm{C} ; T_{R E F}=100{ }^{\circ} \mathrm{C}\right)$, and $I s O_{I}$ and $I s o_{F}$ is the time at which the isothermal stage on treatment is initiated and terminated, respectively $(\mathrm{min})$.

The reactor was heated to the desired temperature described in Table $1\left(140{ }^{\circ} \mathrm{C}, 160\right.$ ${ }^{\circ} \mathrm{C}, 180{ }^{\circ} \mathrm{C}$, and $200{ }^{\circ} \mathrm{C}$ and maintained in isothermal regime for $15 \mathrm{~min}$ ). A control was established at a severity factor of 1.14 at $100{ }^{\circ} \mathrm{C}$ for $10 \mathrm{~min}$. Once the desired severity factor was accomplished, the reactor was immediately cooled. The reactor was opened until the temperature decreased to $80{ }^{\circ} \mathrm{C}$ (Rios-Gonzalez et al., 2017). The pretreated material was separated by filtration, washed with a water volume of 30 times the volume of the material to eliminate the presence of inhibitors adhered to the solids, and stored at $4{ }^{\circ} \mathrm{C}$ before performing the enzymatic hydrolysis tests. The contents of glucan, xylan, and lignin in the solid fractions were determined as described in the previous section. The liquid fraction was analyzed by high-performance liquid chromatography (HPLC) to determine the concentration of sugars (glucose and xylose).

\section{Enzymatic Hydrolysis}

Cellic ${ }^{\circledR}$ CTec3 (kindly provided by Novozymes A/S, Denmark) enzyme complex was used to hydrolyze the pretreated solids (FPase $=217 \mathrm{FP}$ units $/ \mathrm{mL}$ ). Processing was done according to the NREL/TP-510-42629 protocol (Selig et al. 2008). The experiments were carried out in $125 \mathrm{~mL}$ Erlenmeyer flasks (working volume of $30 \mathrm{~g}$ ) using solids and enzyme loadings of $10 \%$ (w/v) and 25 FPU (Filter Paper Units)/g of glucan, respectively, in $0.05 \mathrm{M}$ sodium citrate buffer at a $\mathrm{pH}$ of 4.8 . Reaction flasks were incubated at $50{ }^{\circ} \mathrm{C}$ in an orbital shaker (New Brunswick TM124/24R, NY, USA) at $200 \mathrm{rpm}$ for $72 \mathrm{~h}$. Samples were centrifuged, filtered, and analyzed by HPLC to quantify the glucose concentration. The enzymatic hydrolysis yields were expressed as the ratio between the amount of glucose released during hydrolysis and the initial amount of structural glucose present in the pretreated material (hydrolysis efficiency) or in the raw material (Table 1). The glucan (highest value obtained) and xylan (lowest values obtained) content in the solid fraction and the enzymatic hydrolysis yield (highest value obtained) were selected to be used in the 
enzymatic hydrolysis stage.

\section{Enzymatic Hydrolysis (Experimental Design)}

A $3^{2}$ full randomized factorial design was used in the present study for the pretreated solid selected. In this design, two factors were assessed at 3 levels each: solids loading (\%, w/v) and enzyme loading (FPU/g of glucan), as shown in Table 2 . The amount of glucose released was selected as the independent variable. Three controls were maintained using material with no pretreatment and with an enzyme loading of $25 \mathrm{FPU} / \mathrm{g}$ glucan at three levels of solid loadings.

\section{Ethanol Production}

The hydrolysate obtained under optimal conditions was centrifuged at 5,082 $\mathrm{rcf}$ for 15 min in a Thermo Scientific centrifuge (Haraeus Megafuge ${ }^{\mathrm{TM}} 16 \mathrm{R}$, Rockford IL, USA). Subsequently, the hydrolysate was supplemented with: yeast extract $(10 \mathrm{~g} / \mathrm{L})$, monopotassium phosphate $(1.17 \mathrm{~g} / \mathrm{L})$, calcium chloride $(0.09 \mathrm{~g} / \mathrm{L})$, magnesium sulfate $(0.36 \mathrm{~g} / \mathrm{L})$, and ammonium sulfate $(4.14 \mathrm{~g} / \mathrm{L})$ and fermented using Saccharomyces cerevisiae ATCC 4126 in a $125 \mathrm{~mL}$ Erlenmeyer flask with a working volume of $50 \mathrm{~mL}$. The medium was supplemented with $15 \mathrm{~mL} / \mathrm{L}$ of a salts solution containing: sodium chloride $(1.26 \mathrm{~g} / \mathrm{L})$, cupric sulfate $(0.26 \mathrm{~g} / \mathrm{L})$, ferrous sulfate $(0.22 \mathrm{~g} / \mathrm{L})$, manganese chloride $(0.12 \mathrm{~g} / \mathrm{L})$, and zinc chloride $(0.32 \mathrm{~g} / \mathrm{L})$. The $\mathrm{pH}$ of the hydrolysate was adjusted to 5.5 with $2 \mathrm{M} \mathrm{NaOH}$ before inoculation. The flasks were incubated in an orbital shaker at $35^{\circ} \mathrm{C}$ and $150 \mathrm{rpm}$ for $24 \mathrm{~h}$. Samples were taken at $0,2,4,6,8,10,12,18$, and $24 \mathrm{~h}$ for ethanol and glucose quantification by HPLC. The enzymatic hydrolysis yield is expressed as the relationship between the amount of glucose released during processing and the initial amount of glucan present in the pretreated solids. The ethanol yield is reported as a percentage of the theoretical yield assuming all of the potential glucose present can be fermented, with a maximum theoretical ethanol yield of $0.51 \mathrm{~g}$ ethanol/g glucose.

\section{Analytical Methods}

The glucose, xylose, and ethanol were determined using an HPLC unit (Agilent 1260 Infinity, Santa Clara, CA, USA) equipped with a refractive index detector at $45^{\circ} \mathrm{C}$, using an Agilent Hi-Plex $\mathrm{H}$ column at $35^{\circ} \mathrm{C}(7.7 \times 300 \mathrm{~mm})$ and $5 \mathrm{mM} \mathrm{H}_{2} \mathrm{SO}_{4}$ as the mobile phase at a flow rate of $0.5 \mathrm{~mL} / \mathrm{min}$.

\section{Data Analysis}

All experiments were performed in triplicate, and the average values are reported. An analysis of variance (ANOVA) was conducted along with Fisher's F test with a $p$ value of $<0.05$ (Minitab $^{\circledR}$ version 17, Minitab Inc., State College, PA, USA).

\section{RESULTS AND DISCUSSION}

\section{Material Composition}

The composition analysis of the raw castor plant pruning residues (dry basis w/w) showed that polysaccharides content was $42.1 \%$, where the main component is glucans at $32.3 \%$, followed by the extractives $(23.3 \%)$, lignin $(23.3 \%)$, xylans $(9.78)$, ash $(5.73 \%)$, and proteins $(3.68 \%)$. The glucan and xylan content were below those reported by Vinayaka et al. (2017) of $45 \%$ and $30 \%$, respectively, with the difference being that only 
the stems were used. The stems have a higher content of structural carbohydrates (glucan and xylan) compared to the leaves and petioles (data not shown, obtained in preliminary studies); in addition, the farming conditions of each crop play an important role in these findings. Van der Weijde et al. (2017) mentioned that longer exposure to drought stress challenges the plants to modify their cell walls to sustain growth under conditions with reduced water potential. The extractives content is similar to other values found in the literature (Mukhopadhyay et al. 2011), which are commonly found secondary metabolite compounds with properties beneficial to health (Alugah and Ibraheem, 2014; Soni et al. 2017). Some of these secondary metabolites are soluble in water and can be extracted by hydrothermal treatments such as autohydrolysis (at low temperatures $<100{ }^{\circ} \mathrm{C}$ ) as a pretreatment stage with high temperatures.

\section{Autohydrolysis Pretreatment}

The composition of castor plant pruning residues after autohydrolysis pretreatment at the different severity factors assayed are shown in Table 1. An increase in the temperature from $100{ }^{\circ} \mathrm{C}$ to $160{ }^{\circ} \mathrm{C}$ only produced an increase in $2.2 \%$ of xylan hydrolysis. At $180{ }^{\circ} \mathrm{C}$ and $200{ }^{\circ} \mathrm{C}$, the xylan hydrolysis was higher (44\% and $77.5 \%$, respectively). The glucan content in the recovered solids after all pretreatments was higher compared to the untreated material (increasing from $34.2 \%$ to 50.3\%). In experiments carried out at the maximum SF assessed (3.37), 83\% of the glucan content remained in the solid fraction. Additionally, in all experiments, lignin was not significantly solubilized during the autohydrolysis pretreatment. The results obtained in the present study are similar to previous reports (Morales-Martínez et al. 2017; Ortiz-Méndez et al. 2017; Ríos-González et al. 2017), in which xylan was hydrolyzed during pretreatment, while the glucan and insoluble lignin were retained in the solid fraction.

As expected, the recovered solids (solids remaining after pretreatment, based on the initial biomass weight) decreased when the SF increased. Thus, the recovered solids ranged from $53.4 \%$ to $94.5 \%$, corresponding to the highest $(\mathrm{SF}=3.37$ ) and the lowest severity factor $(\mathrm{SF}=1)$, respectively. This loss is attributed to the extractives and the xylan that were removed during autohydrolysis pretreatment.

The enzymatic hydrolysis of the pretreated solids also showed an increase as the SF increased, obtaining higher hydrolysis yields that ranged from $52.0 \%$ to $97.8 \%$ with SFs of 1.0 to 3.37, respectively. This behavior was also observed by Bateni et al. (2014), who reported an improvement in the hydrolysis of castor plant residues in samples pretreated with $8 \%(\mathrm{w} / \mathrm{v}) \mathrm{NaOH}$ solution at a high temperature for a longer time $\left(100{ }^{\circ} \mathrm{C}\right.$ for $60 \mathrm{~min}$ ) that caused a higher degree of hydrolysis of some parts of the hemicellulose, which mainly consist of xylan. Because enzymatic pretreatment presents a higher specificity and does not generate high concentrations of inhibitory products, this process is regarded as slow compared to physical and chemical pretreatment methods. This was mentioned by Mukhopadhyay et al. (2011), who reported a maximum delignification of castor plant residues after $6 \mathrm{~h}$ of enzymatic pretreatment. Finally, after analyzing the results obtained (considering glucan preservation, xylan removal and hydrolysis yield), the solids pretreated at an SF of 3.37 (200 ${ }^{\circ} \mathrm{C}$ for $15 \mathrm{~min}$ ) were selected for the following process of enzymatic hydrolysis. 
Table 1. Composition of Solids and Liquid Fractions after of Autohydrolysis Pretreatment of Castor Plant Pruning Residues

\begin{tabular}{|c|c|c|c|c|c|}
\hline Temperature $\left({ }^{\circ} \mathbf{C}\right)$ & 100 & 140 & 160 & 180 & 200 \\
\hline $\boldsymbol{R}_{0}$ & 1.14 & 3.25 & 4.03 & 4.84 & 5.78 \\
\hline Recovered solids (\%) & $\begin{array}{c}94.53 \pm \\
1.9\end{array}$ & $89.15 \pm 1.3$ & $\begin{array}{c}87.30 \pm \\
1.7\end{array}$ & $\begin{array}{c}63.45 \pm \\
0.91\end{array}$ & $\begin{array}{c}53.35 \pm \\
1.1\end{array}$ \\
\hline Loss solids (\%) & $5.47 \pm 1.9$ & $10.85 \pm 1.3$ & $\begin{array}{c}12.70 \pm \\
1.7\end{array}$ & $\begin{array}{c}36.55 \pm \\
0.91\end{array}$ & $\begin{array}{c}46.65 \pm \\
1.1 \\
\end{array}$ \\
\hline \multicolumn{6}{|l|}{$\begin{array}{l}\text { Solids composition (g / } \\
\left.100 g_{D W M}\right)^{a}\end{array}$} \\
\hline Glen & $\begin{array}{l}34.23 \pm \\
1.2\end{array}$ & $36.32 \pm 1.4$ & $\begin{array}{c}37.08 \pm \\
1.3\end{array}$ & $\begin{array}{l}46.92 \pm \\
0.96\end{array}$ & $\begin{array}{l}50.28 \pm \\
1.6\end{array}$ \\
\hline Xyln & $\begin{array}{c}10.24 \pm \\
0.38 \\
\end{array}$ & $\begin{array}{c}10.85 \pm \\
0.24 \\
\end{array}$ & $\begin{array}{c}10.84 \pm \\
0.19 \\
\end{array}$ & $\begin{array}{l}8.57 \pm \\
0.32 \\
\end{array}$ & $\begin{array}{l}4.08 \pm \\
0.15 \\
\end{array}$ \\
\hline$\overline{K L}$ & $\begin{array}{c}24.61 \pm \\
0.31\end{array}$ & $26.1 \pm 0.52$ & $\begin{array}{c}26.65 \pm \\
0.26\end{array}$ & $\begin{array}{c}36.65 \pm \\
0.43\end{array}$ & $\begin{array}{c}44.94 \pm \\
0.71\end{array}$ \\
\hline \multicolumn{6}{|c|}{$\begin{array}{l}\text { Solid fraction removed (g / } \\
\left.100 g_{D W M}\right)^{a}\end{array}$} \\
\hline Glen & $0 \pm 0$ & $0 \pm 0$ & $0 \pm 0$ & $8.1 \pm 0.93$ & $\begin{array}{l}17 \pm \\
1.35\end{array}$ \\
\hline Xyln & $0 \pm 0$ & $0 \pm 0$ & $2.2 \pm 0.13$ & $44 \pm 0.61$ & $\begin{array}{c}77.5 \pm \\
0.62\end{array}$ \\
\hline $\mathrm{KL}$ & $0 \pm 0$ & $0 \pm 0$ & $0 \pm 0$ & $0 \pm 0$ & $0 \pm 0$ \\
\hline \multicolumn{6}{|c|}{ Liquid composition (g/L) } \\
\hline Glc & $0 \pm 0$ & $0 \pm 0$ & $0 \pm 0$ & $0.56 \pm 0.3$ & $\begin{array}{l}0.94 \pm \\
0.45\end{array}$ \\
\hline Xyl & $0 \pm 0$ & $0 \pm 0$ & $\begin{array}{c}0.04 \pm \\
0.01\end{array}$ & $\begin{array}{l}0.62 \pm \\
0.09\end{array}$ & $\begin{array}{l}1.60 \pm \\
0.19\end{array}$ \\
\hline FA & $0 \pm 0$ & $0.55 \pm 0.02$ & $0.8 \pm 0.04$ & $\begin{array}{l}1.85 \pm \\
0.05\end{array}$ & $\begin{array}{c}1.75 \pm \\
0.09\end{array}$ \\
\hline AA & $0 \pm 0$ & $0.11 \pm 0.07$ & $\begin{array}{c}0.36 \pm \\
0.04\end{array}$ & $2.2 \pm 0.01$ & $\begin{array}{l}4.5 \pm \\
0.08\end{array}$ \\
\hline FUR & $0 \pm 0$ & $0 \pm 0$ & $0 \pm 0$ & $\begin{array}{l}0.11 \pm \\
0.01\end{array}$ & $\begin{array}{c}0.49 \pm \\
0.02\end{array}$ \\
\hline \multicolumn{6}{|c|}{$\begin{array}{l}\text { Enzymatic hydrolysis (72 } \\
\text { h) }\end{array}$} \\
\hline Glucose (g/L) & $\begin{array}{l}23.43 \pm \\
0.34\end{array}$ & $\begin{array}{l}27.78 \pm \\
0.16\end{array}$ & $\begin{array}{c}30.35 \pm \\
0.81\end{array}$ & $\begin{array}{c}43.51 \pm \\
0.25\end{array}$ & $\begin{array}{c}54.06 \pm \\
0.72\end{array}$ \\
\hline Hydrolysis Yield (\%) & $\begin{array}{c}51.99 \pm \\
0.34\end{array}$ & $\begin{array}{c}61.44 \pm \\
0.16\end{array}$ & $\begin{array}{c}74.4 \pm \\
0.81\end{array}$ & $\begin{array}{l}84.31 \pm \\
0.25\end{array}$ & $\begin{array}{c}97.77 \pm \\
0.72\end{array}$ \\
\hline
\end{tabular}

a: DWM: dry-weight mass. Solid composition represent the amount of solids recovered after the pretreatment at different severity factors (SF): KL: Klason lignin; Glcn: glucans; Xyln: xylans. Liquid composition represents the amount of components released: Glc: glucose; Xyl: xylose; FA:

formic acid; AA: acetic acid; and FUR: furfural; HMF was not detected

\section{Enzymatic Hydrolysis}

Table 2 shows the results obtained for the enzymatic hydrolysis of the pretreated material using Cellic ${ }^{\circledR} \mathrm{CTec} 3$ at different solids and enzyme loadings. The increase in the solids loading from $10 \%$ to $20 \%$ significantly increased the release of glucose $(52.2 \mathrm{~g} / \mathrm{L}$ to $99.9 \mathrm{~g} / \mathrm{L}$ respectively). Figure 1 shows that the increase of solids loading caused a slight decrease in the hydrolysis yield ( $94.5 \%$ to $90.3 \%$, respectively). 
Table 2. Enzymatic Hydrolysis of the Pretreated Material at Different Solids and Enzyme Loadings

\begin{tabular}{|c|c|c|c|c|}
\hline $\begin{array}{c}\text { Experiment } \\
\text { No. }\end{array}$ & $\begin{array}{c}\text { Solids Loading } \\
(\% \mathbf{w} / \mathbf{w})\end{array}$ & $\begin{array}{c}\text { Enzyme } \\
\text { Loading (FPU/g } \\
\text { glucan) }\end{array}$ & Glucose (g/L) & $\begin{array}{c}\text { Hydrolysis } \\
\text { Yield (\%) }\end{array}$ \\
\hline 1 & 20 & 25 & $103.76 \pm 0.49$ & 93.81 \\
\hline 2 & 20 & 20 & $100.46 \pm 0.57$ & 90.83 \\
\hline 3 & 20 & 15 & $95.52 \pm 1.34$ & 86.36 \\
\hline 4 & 15 & 25 & $79.19 \pm 0.82$ & 95.46 \\
\hline 5 & 15 & 20 & $76.91 \pm 0.99$ & 92.71 \\
\hline 6 & 15 & 15 & $73.69 \pm 0.34$ & 88.83 \\
\hline 7 & 10 & 25 & $54.36 \pm 0.93$ & 98.31 \\
\hline 8 & 10 & 20 & $52.24 \pm 0.49$ & 94.47 \\
\hline 9 & 10 & 15 & $50.19 \pm 0.77$ & 90.76 \\
\hline US (Control 1) & 20 & 25 & $35.11 \pm 0.82$ & 31.75 \\
\hline US (Control 2) & 15 & 25 & $28.65 \pm 0.72$ & 34.54 \\
\hline US (Control 3) & 10 & 25 & $19.96 \pm 0.24$ & 36.10 \\
\hline
\end{tabular}

US: Untreated Solid

The maximum glucose released $(103.8 \mathrm{~g} / \mathrm{L})$ was observed in the experiments with the highest values of solids and enzyme loadings (20\% and 25 FPU/g glucan, respectively). Under these conditions as previously mentioned but using the nonpretreated material (Control 1), the glucose released (35.1 g/L) and the hydrolysis yield (31.8\%) were 2.9-fold lower. Similar results were reported by Mukhopadhyay et al. (2011), with a 2.68-fold increase in reducing sugars release yields during enzymatic hydrolysis of castor plant biomass pretreated by laccases compared with non-pretreated castor plant biomass. Bateni et al. (2014) carried out the hydrolysis of castor plant residues (stem, leaves and seed cake) and reported the results separately, mentioning that an improvement was observed in the hydrolysis yield of pretreated material with alkali at $100{ }^{\circ} \mathrm{C}$ for $60 \mathrm{~min}(82.9 \%, 35.4$ and $61.3 \%$ for stem, leaves and seed cake, respectively) compared to non-pretreated material $(36.1 \%, 18.2 \%$ and $7.6 \%$ for stem, leaves and seed cake, respectively).

According to Fig. 1 and the ANOVA analysis (Table 3), the factor with more significance was solids loading, where at high levels, the higher hydrolysis yield was obtained. For enzyme loading, its significance was low in all of the levels evaluated. This could represent an advantageous feature of our process.

Table 3. Analysis of Variance

\begin{tabular}{|c|c|c|c|c|c|}
\hline Factors & DOF & Sums of squares & Variance & F-Ratio & p \\
\hline Solids loading & 2 & 6812.128 & 3406.064 & 3039.395 & 0.000000 \\
\hline Enzyme loading & 2 & 107.753 & 53.877 & 48.077 & 0.000016 \\
\hline Solids vs Enzyme loading & 4 & 9.128 & 2.282 & 2.036 & 0.172600 \\
\hline Other/Error & 9 & 10.086 & 1.121 & & \\
\hline Total & 17 & 6939.095 & & & \\
\hline
\end{tabular}

$p<0.05=$ Higher factor significance

These results show that by using low levels of enzyme, high hydrolysis is obtained. In the same regard, high solid loading favor hydrolysis. This represents low cost in enzymes and high amount of substrate. Also, the results show that at even higher solids loading, even higher hydrolysis yield may be obtained. 


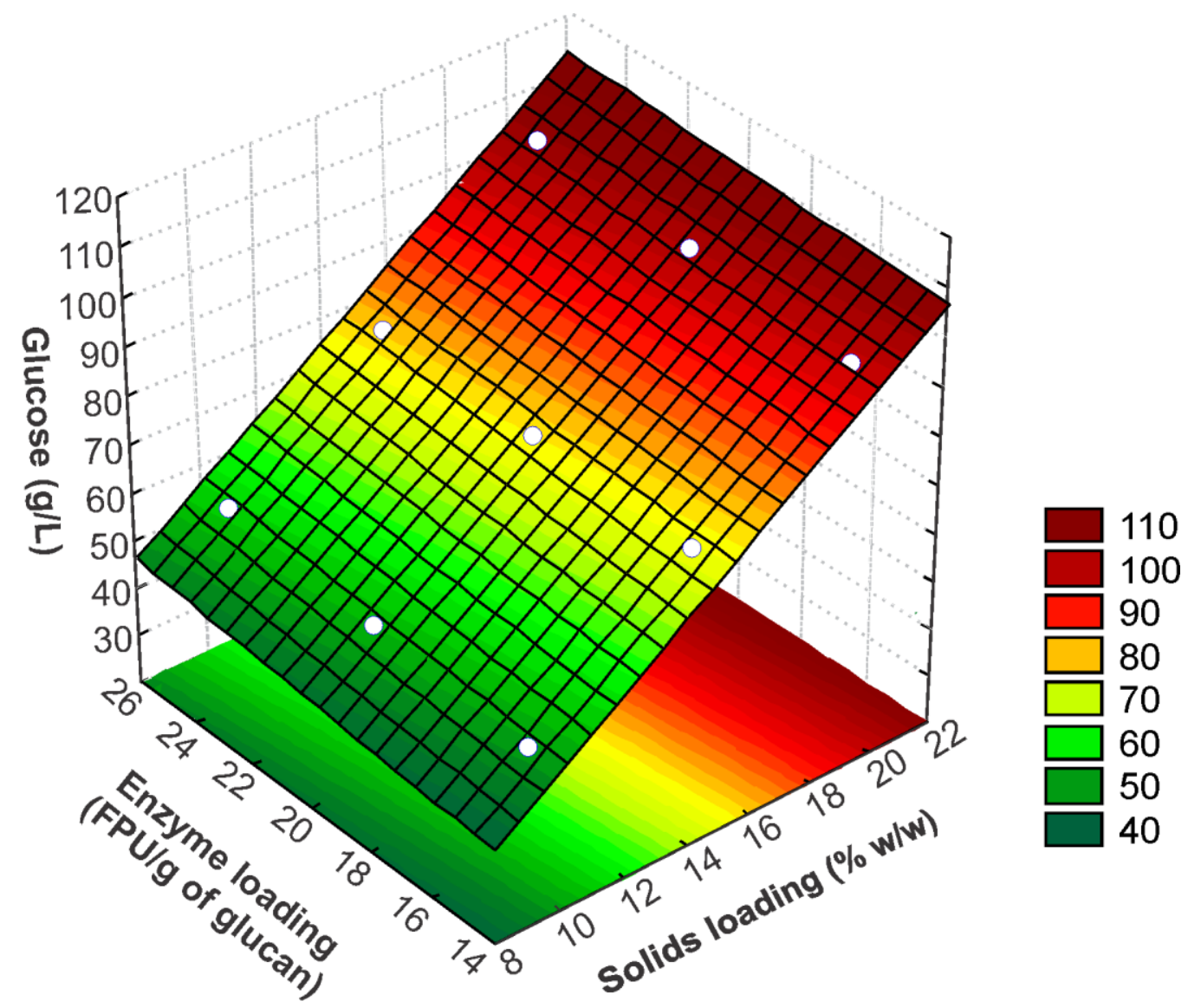

Fig. 3. Effect of the variables in enzymatic hydrolysis of castor plant

In the actual results of the evaluated treatments (Table 2), even though the highest glucose release observed was in the cases where the highest enzyme loading was used (Experiments 1, 4, and 7), the difference in glucose release on average was only $5.97 \mathrm{~g} / \mathrm{L}$ compared to the experiments with the lowest enzyme loading used (Experiments 3, 6, and 9). This slight difference can be attributed to the blockage of active sites of cellulase due to the high content of lignin present in the pretreated material (Althuri et al. 2017) or by the inhibition of the enzymatic complex due to hydrolysis products, such as glucose and cellobiose. According to Morales-Martinez et al. (2017), an increase of 50\% in enzyme loading could be justified only if the increase in the hydrolysis yield was greater than $6 \%$. Therefore, the enzyme loading can be optimized to provide the maximum glucose concentration at the lowest unit cost (Wang et al. 2012). With the goal of obtaining the highest possible ethanol yield $(0.51 \mathrm{~g}$ of ethanol per $\mathrm{g}$ of glucose), the hydrolysates with the highest glucose concentration (Experiment 1) were used in the subsequent fermentation stages.

\section{Fermentation of Hydrolysates}

Figure 1 shows the ethanol production and glucose consumption from hydrolysates of castor plant pruning pretreated by autohydrolysis. The maximum ethanol produced was $50.5 \mathrm{~g} / \mathrm{L}$ (equivalent to $6.4 \% \mathrm{v} / \mathrm{v}$ ) at $12 \mathrm{~h}$ of incubation, and at this same time, glucose was totally consumed. The ethanol concentration obtained corresponds to an ethanol yield of $\left(\mathrm{Y}_{\mathrm{E} / \mathrm{G}}\right) 0.50 \mathrm{~g}_{\text {ethanol }} / \mathrm{g}_{\mathrm{glucose}}$ consumed and a conversion efficiency $(\mathrm{CE})$ of $98 \%$ according to the theoretical value. The biomass to ethanol conversion yield $\left(\mathrm{Y}_{\mathrm{E} / \mathrm{B}}\right)$ was $93.0 \mathrm{~g}$ of ethanol per 
kilogram of raw castor plant pruning residues. The results obtained in the present work regarding the $\mathrm{Y}_{\mathrm{E} / \mathrm{B}}$ were greater than those reported by Bateni et al. (2014), with $63 \mathrm{~g}$ of ethanol per kilogram of castor stems pretreated with $\mathrm{NaOH}$ at $100{ }^{\circ} \mathrm{C}$ for $60 \mathrm{~min}$. In another report (Althuri et al. 2017), a higher ethanol concentration was produced $(62.0 \mathrm{~g} / \mathrm{L}$ equivalent to $7.86 \mathrm{v} / \mathrm{v}$ ) compared to the results of the present work; however, in this case, the material used by the authors had a composition of $40 \%$ of Saccharum spontaneum L. and Saccharum officinarum L. These two species have been reported to have a high content of glucan, which can explain the greater sugar and ethanol production in the hydrolysis and fermentation stages, respectively. Further research will be focused on maintaining the high hydrolysis yield obtained in the present work and improving the processes for extraction and conservation of biomolecules of interest.

\section{CONCLUSIONS}

1. The autohydrolysis pretreatment of castor plant pruning residues was found to be an efficient method. This pretreatment favored enzymatic hydrolysis, obtaining high yields.

2. Castor crops have potential to be used as raw material for a biorefinery process using the whole plant. The main objective of the autohydrolysis process is to avoid the use of chemicals, allowing for a higher preservation of the bioactive molecules of interest present in the extracts.

3. The pretreatment should be carried out at temperatures under $180{ }^{\circ} \mathrm{C}$ and with a reaction time equivalent to an $\mathrm{SF}$ of 3.37.

4. The ethanol production was efficient, accumulating up to $50.5 \mathrm{~g} / \mathrm{L}$ in 12 hours with the glucose available was consumed in its totality adjusting to the theoretical yields for ethanol production. This result confirms the viability of the biomass as an extended use of the material regarding biofuels production.

\section{ACKNOWLEDGMENTS}

The authors are grateful to the Secretariat of Energy of Mexico (SENER) and the Bioenergy Thematic Network ("Red Mexicana de Bioenergía”) Grant 260457 for the financial support provided through the National Council of Science and Technology of Mexico (CONACyT).

\section{REFERENCES CITED}

Althuri, A., Gujjala, L. K. S., and Banerjee, R. (2017). "Partially consolidated bioprocessing of mixed lignocellulosic feedstocks for ethanol production,"

Bioresource Technology 245, 530-539. DOI: 10.1016/j.biortech.2017.08.140

Alugah, C. I., and Ibraheem, O. (2014). "Whole plant screenings for flavonoids and tannins contents in castor plant (Ricinus communis L.) and evaluation of their biological activities," International Journal of Herbal Medicine 2, 68-76. 
http://www.florajournal.com/vol2issue2/june2014/18.1.pdf

Bateni, H., Karimi, K., Zamani, A., and Benakashani, F. (2014). "Castor plant for biodiesel, biogas, and ethanol production with a biorefinery processing perspective," Applied Energy 136, 14-22. DOI: 10.1016/j.apenergy.2014.09.005

Bauddh, K., Singh, K., Singh, B., and Singh, R. P. (2015). "Ricinus communis: A robust plant for bio-energy and phytoremediation of toxic metals from contaminated soil," Ecological Engineering 84, 640-652. DOI: 10.1016/j.ecoleng.2015.09.038

Chornet, E., and Overend, R. P. (2017). "How the severity factor in biomass hydrolysis came about," in: Hydrothermal Processing in Biorefineries, H. Ruiz, M. Hedegaard Thomsen, and H. Trajano (eds.) Springer, New York. DOI: 10.1007/978-3-31956457-9_1

Díaz-Blanco, D. I., de la Cruz, J. R., López-Linares, J. C., Morales-Martínez, T. K., Ruiz, E., Ríos-González, L. J., Romero, I., and Castro, E. (2018). "Optimization of dilute acid pretreatment of Agave lechuguilla and ethanol production by co-fermentation with Escherichia coli MM160," Industrial Crops and Products 114, 154-163. DOI: 10.1016/j.indcrop.2018.01.074

Fideicomiso de Riesgo Compartido (FIRCO) (2017). "Inauguración de planta extractora de aceite de higuerilla," (https://www.gob.mx/firco/prensa/inauguracion-de-plantaextractora-de-aceite-de-higuerilla?idiom=es), Accessed 28 May 2018.

Jiang, L., Wu, Y., Wu, N., Zhong, H., Zhang, Y., Zhao, Z., and Zhang, F. (2020).

"Selective saccharification od microwave-assisted glycerol pretreated corncobs via fast pyrolysis and enzymatic hydrolysis," Fuel 265, 116965. DOI: 10.1016/j.fuel.2019.116965

Kaur, R., Gera, P., Jha, M. K., and Bhaskar, T. (2018). "Pyrolysis kinetics and thermodynamic parameters of castor (Ricinus communis) residue using thermogravimetric analysis," Bioresource Technology 250, 422-428. DOI: 10.1016/j.biortech.2017.11.077

Kumar, A., Chatterjee, S., Hemalatha, M., Althuri, A., Min, B., Kim, S., and Mohan, S. (2020). "Deoiled algal biomass derived renewable sugars for bioetanol and biopolymer production in biorefinery framework," Bioresource Technology 296, 122315. DOI: 10.1016/j.biortech.2019.122315

Montero, G., Stoytcheva, M., Coronado, M., Garcia, C., Cerezo, J., Toscano, L., Vázquez, A. M., and León, J. A. (2015). "An overview of biodiesel production in Mexico," in: Biofuels - Status and Perspective, Intech, London. DOI: 10.5772/59400

Morales-Martínez, T. K., Díaz-Blanco, D. I., Rodríguez-de la Garza, J. A., MorlettChávez J., Castro-Montoya, A. J., Quintero, J., Aroca, G., and Ríos-González, L. J. (2017). "Assessment of different saccharification and fermentation configurations for ethanol production from Agave lechuguilla," BioResources 12, 8093-8105. DOI: 10.15376/biores.12.4.8093-8015

Mukhopadhyay, M., Kuila, A., Tuli, D. K., and Banerjee, R. (2011). "Enzymatic depolymerization of Ricinus communis, a potential lignocellulosic for improved saccharification," Biomass and Bioenergy 35, 3584-3591. DOI: 10.1016/j.biombioe.2011.05.013

Ortíz-Méndez, O. H., Morales-Martínez, T. K., Ríos-González, L. J., Rodríguez-de la Garza, J. A., Quintero, J., and Aroca, G. (2017). "Bioethanol production from Agave lechuguilla biomass pretreated by autohydrolysis," Revista Mexicana de Ingeniería Química 16, 467-476. https://www.redalyc.org/pdf/620/62052087013.pdf

Ríos, González, L. J., Morales Martínez, T. K., Rodríguez Flores, M. F., Rodríguez de la 
Garza, J. A., Castillo Quiroz, D., Castro Montoya, A. J., and Martínez, A. (2017).

"Autohydrolysis pretreatment assessment in ethanol production from agave bagasse," Bioresource Technology 242, 184-190. DOI: 10.1016/j.biortech.2017.03.039

Santhi, T., Manonmani, S., and Smitha, T. (2010). "Removal of malachite green from aqueous solution by activated carbon prepared from the epicarp of Ricinus communis by adsorption," Journal of Hazardous Materials 179, 178-186. DOI:

10.1016/j.jhazmat.2010.02.076

Selig, M., Weiss, N., and Ji, Y. (2008). Enzymatic Saccharification of Lignocellulosic Biomass (TP-510-42629), National Renewable Energy Laboratory, Golden, CO, USA.

Sluiter, A., Hames, B., Ruiz, R., Scarlata, C., Sluiter, J., and Templeton, D. (2008). Determination of Ash in Biomass (TP-510-42622), National Renewable Energy Laboratory, Golden, CO, USA.

Sluiter, A., Ruiz, R., Scarlata, C., Sluiter, J., and Templeton, D. (2005). Determination of Extractives in Biomass (TP-510-42619), National Renewable Energy Laboratory, Golden, CO, USA.

Soni, N., and Dhiman, R. C. (2017). "Phytochemical, anti-oxidant, larvicidal, and antimicrobial activities of castor (Ricinus communis) synthesized silver nanoparticles," Chinese Herbal Medicines 9, 289-294. DOI: 10.1016/S1674-6384 (17)60106-0

Soni, S., Nila, T. B., Tety, S., Eko, P. H., and Bebeh, W. N. (2017). "Alternatif Pembuatan Biodiesel Melalui Transesterifikasi Minyak Castor (Ricinus communis) Menggunakan Katalis Campuran Cangkang Telur Ayam dan Kaolin, ” Jurnal Kimia VALENSI 3(1), 1-10.DOI: 10.15408/jkv.v0i0.4778

Torrentes-Espinoza, G., Miranda, B. C., Vega-Baudrit, J., and Mata-Segreda, J. F. (2017). "Castor oil (Ricinus communis) supercritical methanolysis," Energy 140, 426435. DOI: $10.1016 /$ j.energy.2017.08.122

Tropicos (2018).

(http://www.tropicos.org/NameSearch.aspx?name=Ricinus+communis\&commonnam $\mathrm{e}=)$, Accessed 28 May 2018.

Van der Weijde, T., Huxley, L. M., Hawkins, S., Sembiring, E. H., Farrar, K., Dolstra, O., Visser, R., and Trindade, L. (2017). "Impact of drought stress on growth and quality of Miscanthus for biofuel production," GCB Bioenergy 9, 770-782. DOI: $10.1111 /$ gcbb.12382

Vinayaka, D. L., Guna, V., Madhavi, D., Arpitha, M., and Reddy, N. (2017). "Ricinus communis plant residues as a source for natural cellulose fibers potentially exploitable in polymer composites," Industrial Crops and Products 100, 126-131. DOI: 10.1016/j.indcrop.2017.02.019

Wang, W., Zhuang, X., Yuan, Z., Yu, Q., Qi, W., and Wang, Q. (2012). "High consistency enzymatic saccharification of sweet sorghum bagasse pretreated with liquid hot water," Bioresource Technology 108, 252-257. 10.1016/j.biortech.2011.12.092

Article submitted: April 4, 2020; Peer review completed: May 24, 2020; Revised version received: June 20, 2020; Accepted: June 22, 2020; Published: June 25, 2020.

DOI: 10.15376/biores.15.3.6206-6216 